\title{
Formation of an Innovative and Creative System of Managing the Development of Industrial Enterprises
}

\author{
Viktoriia Chobitok $^{1 *}$, Larisa Chumak $^{1}$, Tetiana Demyanenko ${ }^{1}$, Yulia Us $^{2}$ \\ ${ }^{1}$ Ukrainian Engineering Pedagogical Academy (Kharkiv) \\ ${ }^{2}$ Simon Kuznets Kharkiv National University of Economics (Kharkiv)
}

\begin{abstract}
The article deals with the issues of forming an innovative and creative system of managing the development of industrial enterprises. An analysis of the state of the development of domestic enterprises has been carried out. The essence of the directions of the development of domestic industrial enterprises has been defined. The analysis of the essence of the concept of "enterprise development" has been conducted, with the authors' own definition of the term being provided. Theoretical bases for the formation of the concept of "an innovative and creative system of managing the development of industrial enterprises" have been devised. Types of innovative and creative directions of managing the development of industrial enterprises have been singled out.
\end{abstract}

\section{Introduction}

The world economy at the present stage of its development is characterized by a significant increase in competition. The domestic industrial sector, as a budget-builder, is coming under considerable pressure from major foreign competitors. Effective functioning and constant development of domestic industrial enterprises actively affects the level of social and economic state of the country.

Successful functioning of domestic industrial enterprises, in the modern economic conditions, taking into account the permanent unfavorable influences of external and internal factors on their activity, is possible subject to formation and introduction of innovative and creative management of the development of all their structural elements.

\section{Presenting main material}

Some questions of the formation of an innovative and creative system of managing the development of industrial enterprises have been considered by such scientists as O. Kuzmin

*Corresponding author: vika chobitok@ukr.net 
[1], I. Lapina [3], O. Pashchenko [3], Yu. Pohorelov [4], V. Prokhorova [5], M. Sushko [6], V. Shylova [7] et al. But there still remain a number of debatable issues which concern the effective formation and implementation of an innovative and creative system of managing the development of industrial enterprises with regard to the permanent conditions of the environment, so the problem field under investigation needs further clarification.

The purpose of the research is to form an innovative and creative system of managing the development of industrial enterprises in modern economic conditions.

In the economy of any country a significant role is played by the level of industrial development. In Ukraine, the industry produces about $40 \%$ of the national output of goods and services. The domestic industry has about one third of the main means of production of the total number used in the country's economy. Although the domestic industry is in a difficult condition, it is one of the main sources of salaries for the employed, businessmen's profits, tax revenues, etc.

The indices of industrial production by types of activity for the period 2013-2018, according to the State Statistics Service of Ukraine [9], are given in Table 1.

Table 1. Indices of industrial production by types of activity for 2013-2018, \%.

\begin{tabular}{|l|c|c|c|c|c|c|}
\hline \multirow{2}{*}{ Industry types } & \multicolumn{7}{|c|}{ Years } \\
\cline { 2 - 8 } & 2013 & 2014 & 2015 & 2016 & 2017 & 2018 \\
\hline $\begin{array}{l}\text { Industry } \\
\text { including: }\end{array}$ & 95.7 & 89.9 & 87.0 & 102.8 & 100.4 & 101.6 \\
\hline Mining and quarrying & 100.8 & 86.3 & 85.8 & 99.8 & 94.3 & 102.4 \\
\hline Processing industry & 92.7 & 90.7 & 87.4 & 104.3 & 104.8 & 101.1 \\
\hline $\begin{array}{l}\text { Supply of electricity, gas, } \\
\text { steam and air conditioning }\end{array}$ & 98.9 & 93.4 & 88.0 & 102.5 & 93.5 & 102.8 \\
\hline
\end{tabular}

The data provided in Table 1 were used to plot a histogram of the changes in indices of industrial production by types of activity for 2013-2018. The analysis of changes in indices of industrial production by types of activity for 2013-2018 shows that throughout almost the whole period under study, with the exception of 2018, the volumes of industrial production tended to decrease compared with the previous period, which is strongly related to the influence of internal factors (revolutions, unstable domestic political situation, decrease in the support from the state, constant increase in energy tariffs, raising unemployment, etc.) and external factors (decline in the level of investment in the domestic industry, decrease in the level of competitiveness, military conflicts, etc.). All this results in destabilization of the activity of domestic industry enterprises and negatively affects their level of development. An innovative and creative management system should be formed in order to increase the competitiveness of domestic industrial enterprises. The basis for achieving promising directions in the development of domestic industrial enterprises is the use of intellectual as well as scientific and technological potential in the organizational and economic support of production processes and provision of services. Justification of the priorities in the development of domestic industrial enterprises will help restore their significant role in the economic growth of the country and ensure its level of economy as a whole. 


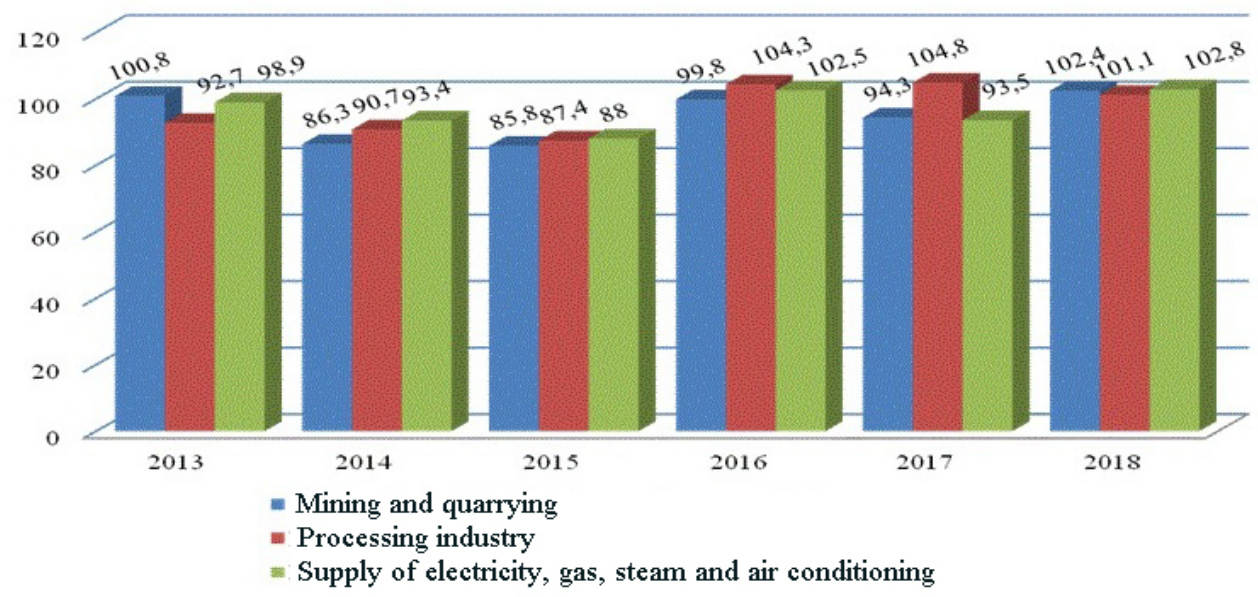

Fig. 1. Histogram of the changes in indices of industrial production by types of activity for 20132018.

The essence of the directions of the development of domestic industrial enterprises is shown in Fig. 2.

\begin{tabular}{|c|}
\hline Directions of the development of domestic industrial enterprises \\
\hline achievement of a positive synergetic effect in all industrial fields \\
\hline $\begin{array}{c}\text { creation of production cycles based on corporate connections between domestic } \\
\text { industrial enterprises }\end{array}$ \\
\hline $\begin{array}{c}\text { development of the domestic sales market for consumer and industrial goods produced at } \\
\text { domestic industrial enterprises }\end{array}$ \\
\hline $\begin{array}{l}\text { increase in the share of goods with a high added value in the total export of goods, } \\
\text { decrease in the negative balance in the international trade in goods }\end{array}$ \\
\hline $\begin{array}{c}\text { technical re-equipment and modernization of manufacturing at domestic industrial } \\
\text { enterprises }\end{array}$ \\
\hline creation of more jobs at domestic industrial enterprises \\
\hline
\end{tabular}

Fig. 2. Directions of the development of domestic industrial enterprises.

In modern economic literature, scientists give multiple different definitions of the essence of the concept of "enterprise development", some of which are presented in Table 2.

Table 2. Definitions of the concept of "enterprise development".

\begin{tabular}{|c|l|}
\hline Author & \multicolumn{1}{c|}{ Definition } \\
\hline V. Andriichuk & $\begin{array}{l}\text { These are irreversible, purposeful and regular changes of the economic system, } \\
\text { the sequence of its transition from one state to a qualitatively different one on the } \\
\text { basis of the improvement of equipment, technology and labor organization as }\end{array}$ \\
\hline
\end{tabular}




\begin{tabular}{|l|l|}
\hline \multicolumn{1}{|c|}{ Author } & \multicolumn{1}{c|}{ Definition } \\
\hline R. Ackoff & $\begin{array}{l}\text { Development is primarily characterized by qualitative changes such as } \\
\text { improvement of technological equipment of manufacturing, professional } \\
\text { development of employees, change of managerial principles and mechanisms, } \\
\text { etc. }\end{array}$ \\
\hline $\begin{array}{l}\text { N. Afanasiev, } \\
\text { V. Gohozhyn, }\end{array}$ & $\begin{array}{l}\text { The objective change only of the qualitative characteristics of the system is } \\
\text { conditioned by both the fundamental laws of nature (unity and struggle of } \\
\text { opposites, transfer of quantity into quality, spiral and upward development of } \\
\text { society) and the laws of the functioning of specific systems (equipment aging, } \\
\text { experience and knowledge acquisition by employees, depletion of natural } \\
\text { resources), as a result of which some new properties of the system are formed }\end{array}$ \\
\hline S. Dunda & $\begin{array}{l}\text { A set of directed, intensive and qualitative changes of the economic nature } \\
\text { occurring at the enterprise as a result of contradictions in the internal } \\
\text { environment and influences of outer factors }\end{array}$ \\
\hline $\begin{array}{l}\text { Economic } \\
\text { Encyclopedia }\end{array}$ & $\begin{array}{l}\text { A natural process of quantitative and qualitative changes within the economic } \\
\text { system, its transition to a new quality, a more perfect form }\end{array}$ \\
\hline O. Kuzmin & $\begin{array}{l}\text { The development of each organization which has a cyclic nature, i.e. passes } \\
\text { through certain stages of the life cycle that determine the features of production, } \\
\text { economic, investment, financial and other activities }\end{array}$ \\
\hline $\begin{array}{l}\text { M. Mescon, } \\
\text { M. Albert, } \\
\text { F. Khedouri }\end{array}$ & $\begin{array}{l}\text { A long-term program for improving problem-solving capabilities and } \\
\text { capabilities for renewal, especially by increasing the effectiveness of managing } \\
\text { the culture of the organization }\end{array}$ \\
\hline O. Raievnieva & $\begin{array}{l}\text { A unique process of transformation of an open system in space and time, } \\
\text { characterized by a permanent change in the global goals of its existence by } \\
\text { means of forming a new dissipative structure, as well as by means of its } \\
\text { transition to a new attractor of functioning (one of the alternative trajectories of } \\
\text { enterprise development) }\end{array}$ \\
\hline
\end{tabular}

The analysis of the essence of the concept of "enterprise development" shows that the authors put forward their own definition of the notion, which they regard as the process of quantitative and qualitative changes taking place at the enterprise under the influence of internal and external factors and leading to an increase in the level of its operational, investment and financial activities through the formation of an innovative and creative management system.

Throughout the history of enterprise development, a system of managerial relations has been formed, with an opportunity to register events being discovered at the beginning of the fifth millennium BC, when the Sumerians invented the cuneiform characters. Since then, humanity has continuously worked on and implemented an innovative and creative management system which has undergone the following stages of development: religious and commercial revolution; secular and administrative revolution; production and construction revolution; industrial revolution; bureaucratic revolution and information revolution.

Theoretical bases for the development of the concept of "an innovative and creative system of managing the development of industrial enterprises" are shown in Fig. 3.

The innovative and creative system of managing the development of industrial enterprises consists in the formation and implementation of purposeful and logical changes in the economic system, the sequence of its transition from one state to a qualitatively different one on the basis of the improvement of equipment, technology, labor organization, 
etc., which is the foundation for increasing their competitiveness on domestic and foreign markets.

\begin{tabular}{|c|c|c|}
\hline Innovations & \multirow{3}{*}{$\begin{array}{l}\mathbf{M} \\
\mathbf{A} \\
\mathbf{N} \\
\mathbf{A} \\
\mathbf{G} \\
\mathbf{E} \\
\mathbf{M} \\
\mathbf{E} \\
\mathbf{N} \\
\mathbf{T}\end{array}$} & Creativity \\
\hline$\downarrow$ & & $\nabla$ \\
\hline $\begin{array}{c}\text { ideas, innovative products, based on } \\
\text { scientific achievements and advanced } \\
\text { experience }\end{array}$ & & $\begin{array}{l}\text { creative potential which is } \\
\text { characterized by the ability to generate } \\
\text { brand-new ideas }\end{array}$ \\
\hline$\downarrow$ & & $\nabla$ \\
\hline Inmovative management & & Creative management \\
\hline$\checkmark$ & $\mathbf{E}$ & $\nabla$ \\
\hline $\begin{array}{l}\text { a process aimed at enhancing } \\
\text { competitiveness through the effective } \\
\text { functioning and development of the } \\
\text { system by means of using innovative } \\
\text { approaches based on scientific } \\
\text { achievements and advanced } \\
\text { experience }\end{array}$ & $\begin{array}{l}\mathbf{E} \\
\mathbf{L} \\
\mathbf{O} \\
\mathbf{P} \\
\mathbf{M} \\
\mathbf{E} \\
\mathbf{N} \\
\mathbf{T}\end{array}$ & $\begin{array}{l}\text { a process aimed at providing the } \\
\text { subjects of management with an } \\
\text { opportumity to generate and develop } \\
\text { brand-new ideas }\end{array}$ \\
\hline$\downarrow$ & $\frac{1}{t}$ & $\nabla$ \\
\hline \multicolumn{3}{|c|}{$\begin{array}{l}\text { Innovative and creative system of managing the development of industrial } \\
\text { enterprises }\end{array}$} \\
\hline $\begin{array}{l}\text { A process of quantitative and qualitat } \\
\text { operational, investment and financial } \\
\text { approaches (scientific achievements an } \\
\text { (development and generation of }\end{array}$ & al en & $\begin{array}{l}\text { ling to the increase in the level of their } \\
\text { a is aimed at implementing innovative } \\
\text { erience) as well as creative approaches } \\
\text { to enhance the competitiveness of } \\
\text { ses }\end{array}$ \\
\hline
\end{tabular}

Fig. 3. Theoretical bases for the formation of the concept of "an innovative and creative system of managing the development of industrial enterprises".

Fig. 4 demonstrates the types of innovative and creative directions of managing the development of industrial enterprises which are most often considered.

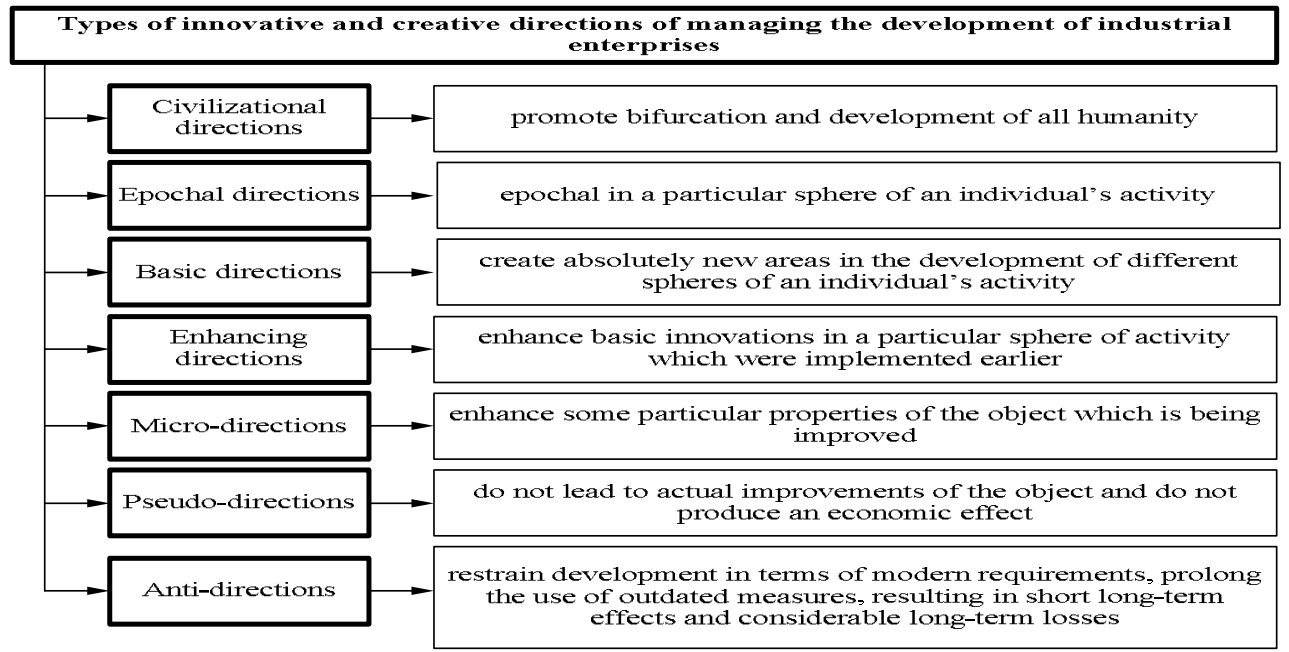


Fig. 4. Types of innovative and creative directions in the management of the development of industrial enterprises.

Certainly, today's growing demand is the introduction of basic and creative innovations into the system of management of industrial enterprises. This will help effectively organize the activity of industrial enterprises in the conditions of constant changes in market requirements. The possibility of introducing an innovative and creative system of managing the development of industrial enterprises becomes a reality through the use of advances in all areas of "high technology".

\section{Conclusions from the conducted research.}

According to the results of the research, it is determined that domestic industrial enterprises need to implement an innovative and creative system of managing the development of industrial enterprises, which will enable them to enhance their competitiveness. Only those managers who have innovative and creative thinking that differs in the originality of views and who are able to act flexibly and constructively in nonstandard situations and form independent judgments can make effective managerial decisions, they achieve their goals, learn from mistakes and are ready to take risks. Leaders who have developed innovative and creative thinking make industrial enterprises brighter, more interesting, turning everything into something brand-new, effective and rational.

\section{References}

1. O. Ye.Kuzmin, D. K .Zinkevich, A. M. Chushak-Holoborodko Naukovyi visnyk of NLTU of Ukraine, 21.2, 146-152 (2011)

2. I. M. Lapina Modern innovative technologies of management, Retrieved from http://klasnaocinka.com.ua/uk/article/suchasni--innovatsiini--tekhnologiyi--upravlinnya.html

3. O. P. Pashchenko. Global and national economic problems, Mykolaiv National University named after V. O. Sukhomlynskyi, 17, 406- 410 (2017)

4. Yu. S.Pohorelov, K. A. Leiko. Economy and region, 6, 58-63 (2015)

5. V. V. Prokhorova, V. M.,Protsenko, V. I.Chobitok Formation of a competitive strategy of enterprises on the basis of innovation-directed investment, Kharkiv, Ukrainian Engineering Pedagogics Academy, 291 (2015)

6. M. Yu.Sushko. Bulletin of economic science of Ukraine, 1, 93-98 (2017)

7. V. V. Shylova Creative technologies in the system of managing foreign economic activity, Retrieved from http://conf.management.fmm.kpi.ua/proc/article/view/62558

8. L. F. Chumak, Bulletin of the University of Dnipropetrovsk, Series "Economics", 20.10/1, 176-181 (2012)

9. Official website of the State Statistics Service of Ukraine, Retrieved from http://www.ukrstat.gov.ua/

10. I.V. Litvin. Scientific Bulletin of NLTU of Ukraine. 21.7, 360-364 (2011) 